の模様をよく示している。ルチルへの転移は既知のよ5に，熱運 動による核の発生の確率に乏しい再編の転移に属する。第 7 図の ような大きい凝集体においてもその一部 (左端)よりルチルの成 長が始っているにすぎない。核発生速度がルチルの成長速度にく らべて小さいために転移した結晶は単結晶ないしはその少数個の 集まりとなっている。発生したルチル核の周囲の微粒子がつぎつ ぎに原子配列を変えながらルチル核に併吞されて板状ルチル結晶 に成長する。これが 1 個の微粒子㕠集体の全部に扣よんで，その 凝集体の転移が完了する。微粒子間の空隍は集まって穴となって 残るだめに，板状晶の大きさはほぼ元の凝集体の大きさに相当し ている。かかる変化が各凝集体ごとに行われてルチルへの転移が 進行する。

硫酸塩溶液の加水分解による酸化チタンが $1000^{\circ} \mathrm{C}$ またはそれ 以上の温度で初めて転移するのにくらべ，この熱分解生成物の転 移温度は著しく低い。これは加水分解物が焼成前にすでにアナタ 一ゼのある程度安定な結晶格子をつくっているのに反し, 熱分解 では分解によって初めて酸化チタンを生じ，安定な格子点に拈ち つく前に熱運動の盛んな高温にさらされるので，ルチル核を生成 し易いためと考えられる。

転移した結晶は皆薄板状をなすが，薄板面は一定していない。 原子充垍密度が小さくて現われ難いと思われる面が出ている場合 も数多く観察される。扣そらく最初にできる微粒子凝集体が薄片 状であるので自由な成長が奶げられ，ルチル核は薄片面に沿って のみ成長し特定の面を現わすことができないのであろう。第 8 図 中の最す大きい板状晶の電子超折像を第 10 図(a)に示す。この 場合の薄片面は (221) ないし（331）に相当する。結晶の規則正 しい外形は第 10 図 (b)に示す格子面が紙面に垂直になっている ために形作られたすのである。多くの場合，結晶の外形および资 は一見 6 回あるいは 3 回の対称性をるっているか炕見えるが, 薄 板面および側面の種類により必ずしもそのような対称性をもって いるとはかぎらない。 (a)

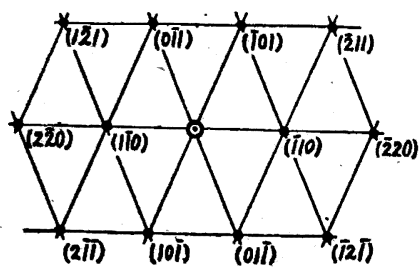

図

( b )

自由な成長をなしえなかった薄板状ルチル結晶は，さらに 1000 ${ }^{\circ} \mathrm{C}$ になると各結晶ごとに厚さの方向に原子が移動して，より安 定な形へと成長して棒状を呈する。

加水分解による酸化チタンやチタニルサルフェートの熱分解に よるあのでは, 各粒子あるいは skeleton 粒子が三次元的な大き さをるっているから，ルチルへの転移に際し ATS 上り自由な成 長をなし，安定な形状となっているので ATS の場合に認められ るような著しい外形変化を行わないるのと考えられる。

総括

ATS の熱分解の過程を明らかにし，生成酸化チタンのX線お よび電子顕微鏡観察を行い，ルチルへの転移の機構を究明した。

ATS は $200^{\circ} \mathrm{C}$ までに 2 分子の結晶水を失い, ついで硫安, $\mathrm{SO}_{3}$ を放って $700^{\circ} \mathrm{C}$ で分解を完了する。この熱分解では，まず アナターゼの微粒子凝集体ができる。この構成微粒子は温度とと

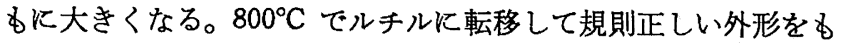
つた薄板状の単結晶あるいはその集まりに成長する。さらに高温 では厚さの方向に成長して棒状晶の集合体となる。

(昭和 28 年 10 月, 山梨地方講演会で一部発表)

終りに臨み, 電子顕微鏡写真の撮影飞格別の御配慮を賜わった 日本電子光学研究所四本晴夫氏, ならびに本学 国富教授の御援 助に深謝する。

\title{
（136）微量酸素の比色定量に用いる $\mathrm{Cu}_{2} \mathrm{Cl}_{2}-\mathrm{NH}_{4} \mathrm{Cl}-\mathrm{NH}_{3}$ 水溶液の組成について
}

(昭 和 30 年 11 月 2 日受理)

伊藤 卓 爾・星野 芳夫*

\section{I. 緒 言}

$\mathrm{N}_{2}, \mathrm{H}_{2}, \mathrm{~A}$ 等のガス中K希溥な状態で混在する微量 $\mathrm{O}_{2}$ ガス の定量には，従来，多くの方法が提案され，使用されている。そ の中， $\mathrm{O}_{2}$ ガスを第一銅塩の $\mathrm{NH}_{3}$ 性溶液と反応させ，生成する 第二舸の青色を比色により定量する方法は多くの長所を持つにも かかわらず，あまり実用化されていない。この方法を実施するに は， $\mathrm{O}_{2}$ ガスと吸収液の一定量を一室に導人し，これを激しくふ りまぜて雨者を反応させるすの（振とう吸収法）と，装置を動か すことなく，吸収液中に $\mathrm{O}_{2}$ を含む試料ガスの気泡を上昇させて 両者を反応させるるの（静止吸収法）との 2 種の形式が考えられ る。文献には前者の形式が多く見られるが1,2), 著者らはこの改 良装置についてすでに報告しだ)。

\footnotetext{
*東京工蔝大学資源化学研究所：東京都目黑区.
}

静止吸収法を実施するには，その形式から考えてとくに $\mathrm{O}_{2}$ ガ スと吸収液の反応速度が大であることが要件であり，このために は装置の棈造と吸収液の組成の両者について検討が加えられなけ ればならない。本報告に拈いては， $\mathrm{Cu}_{2} \mathrm{Cl}_{2}-\mathrm{NH}_{4} \mathrm{Cl}-\mathrm{NH}_{3}$ 吸収液 の組成とその $\mathrm{O}_{2}$ ガス吸収速度および金属 $\mathrm{Cu}$ との平衡下におけ る第二銅濃度の関係について実験を行い, これから吸収溶液組成 の選定に当り考虑すべき諸点を考察した。

\section{II. 実 験 方 法}

$\mathrm{Cu}_{2} \mathrm{Cl}_{2}-\mathrm{NH}_{4} \mathrm{Cl}-\mathrm{NH}_{3}$ 水溶液の $\mathrm{O}_{2}$ ガス吸収速度は一般にかなり 大であり，実験值（吸収率％）はともすれば 100\% に近い㯺所

1) M. Mugdan, J. Sixt, Angew. Chem. 46, 90 (1933).

2) E. Hoffmann, Mikrochem. 82, 25 (1938).

3）伊潾，分析化学 2, 466 (1953). 
に密集し勝ちである。しかしこのような場合には比色の誤差の 影響が大きく入るために結果の解析が困難である。吸収率は大別 して，イ）吸収溶液の性質（組成，温度等），口）吸収装置の性 質（気泡の大きさ，液柱の高さ，すなわち気泡が上杽中溶液に接 する時間, 等), および 八) 試料ガスの濃度, 流速等によって 決定されるが，ある一定の装置を用い，溶液組成を種々に変えて 測定した吸収率の一連の数值相互間の関係は他の吸収装置を用い ても大きな変化がなく，そのまま保たれると考えられるので，溶 液の各組成に対応した吸収率の值が 0〜100\% の全域になるべく 厇い範围にわたって出ることが望ましい。

第 1 图実験装置

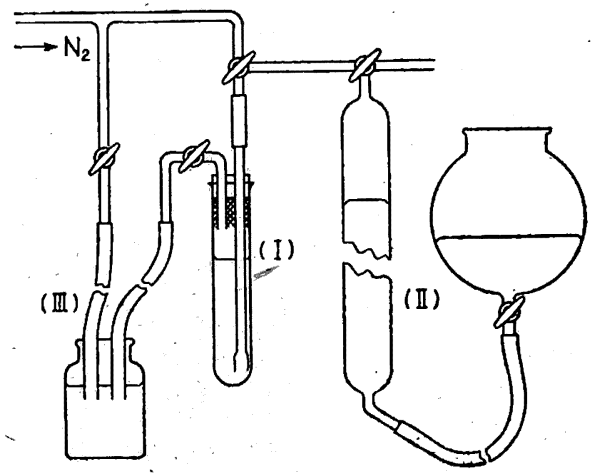

以上の点を考虑して吸収率の測定には第 1 図のような装置を用 いた。（I）は $\mathrm{O}_{2}$ ガスの吸収部分で吸収器には $30 \mathrm{cc}$ 内容の試 験管を用い，ゴム栓を施して 2 管を通し，一方はガスの流入用で 下端は下向きとし，かつ広く拻げて気泡が大となるようにしてあ る。管の上部には $\mathrm{Cu}$ 網を取付け, 溶液の装入後, 管を倒立振と 万して溶液と $\mathrm{Cu}$ 網を接触させることにより，操作中 $\mathrm{Cu}(\mathrm{I})$ の酸 化によって生成した微量の $\mathrm{Cu}(\mathrm{II})$ を還元するのに便なようにし た。（II）は一定組成，量の $\mathrm{O}_{2}$ ガスを調製する部分であり，これ には一定量の空気を $\mathrm{N}_{2}$ ガスで希釈したものを用いた。ガスの送 入, 送出には Hg. を用いた。(III) は（I）からの廃がス拈よび ポンベからの過剩 $\mathrm{N}_{2}$ の出口で水により外気と遮断してある。こ れはまたガスの圧力を調節する目的も持っている。

測定するには，まず，加熱 $\mathrm{Cu}$ 網上を通して微量混入の $\mathrm{O}_{2}$ を除 去したボンベ $\mathrm{N}_{2}$ を装置内に導入して空気と犆換させたのち，一 定組成の吸収溶液 $20 \mathrm{cc}$ を（I）に入れる。（I）を倒立振と5し て吸収液を還元状態にしたのち（四）のガスビュレットから 2 $\% \mathrm{O}_{2}$ 含有の $\mathrm{N}_{2}$-空気混合ガス $50 \mathrm{cc}$ を $40 \mathrm{cc} / \mathrm{min}$ の流速で送 入し，吸収溶液と反応させる。生成した $\mathrm{Cu}^{(\mathrm{II})}$ の濃度は標準の $\mathrm{Cu}^{(\mathrm{II})}-\mathrm{NH}_{3}$ 溶液と比較することにより測定した。剆定はすべて $25^{\circ} \mathrm{C}$ の恒温室内で行ったものである。

平衡における $\mathrm{Cu}(\mathrm{II})$ 濃度の测定も同一の装置を使用して行っ た。

\section{III. 実験結果および考察}

（1）吸収率に対する $\mathrm{NH}_{3}, \mathrm{NH}_{4} \mathrm{Cl}, \mathrm{Cu}_{2} \mathrm{Cl}_{2}$ 各淟度の影繁

第 2 図は $\mathrm{NH}_{3}$ 濃度, 第 3 図は $\mathrm{NH}_{4} \mathrm{Cl}$ 濃度, 第 4 図は $\mathrm{Cu}_{2} \mathrm{Cl}_{2}$ 濃度とそれぞれ吸収率との関係を示す。

これによれば, $\mathrm{NH}_{3}$ 濃度の增加ととすに吸収率も增加するが, $\mathrm{NH}_{3} 150 \mathrm{~g} / l$ 以上では, その增加の程度は比較的小さい。また, $\mathrm{NH}_{4} \mathrm{Cl}$ の添加はむしろ吸収率を低下させる。 $\mathrm{Cu}_{2} \mathrm{Cl}_{2}$ 濃度は大と なるほど，吸収率もまた大となる。
第 2 図

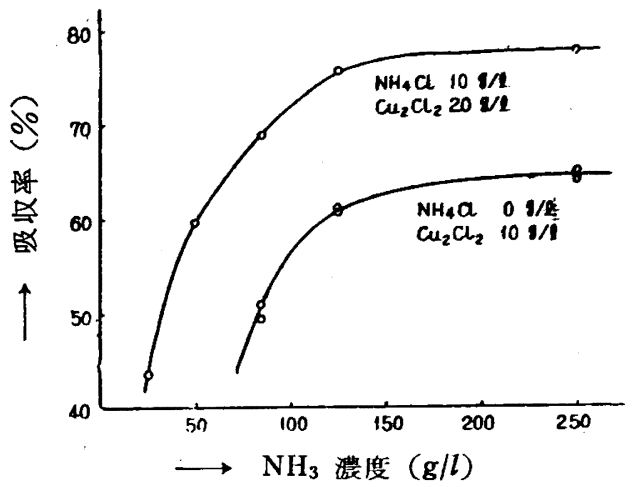

第、3因

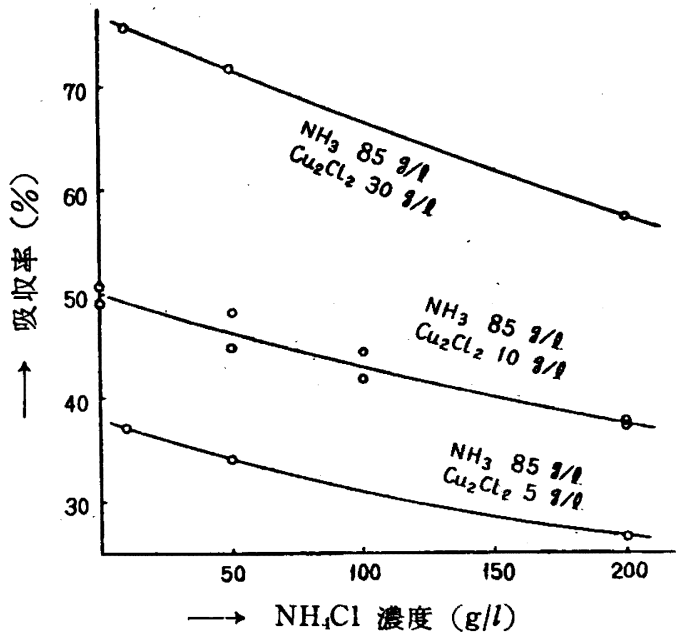

第 -4 図

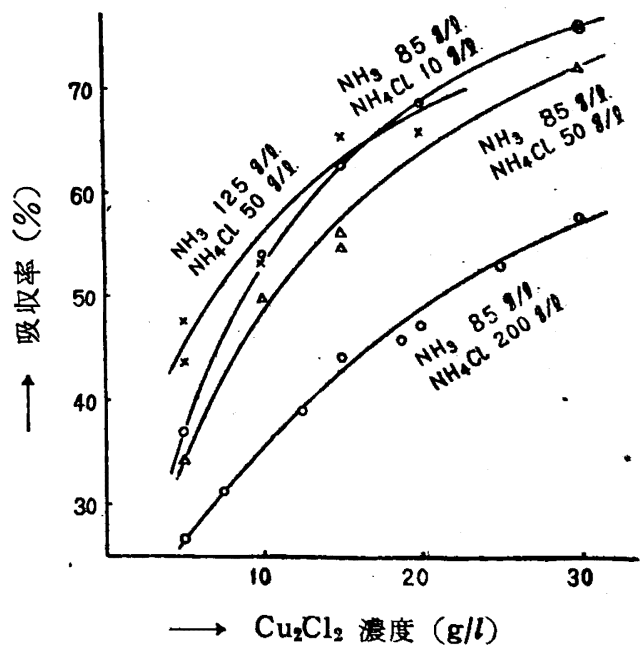

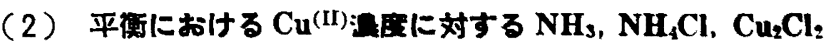
各櫵度の影第

$\mathrm{Cu}_{2} \mathrm{Cl}_{2}$ の $\mathrm{NH}_{3}$ 性液は常に無色の還元状悲に保っておかなけ ればならないので，溶液中には金属銅を共存させて圈くが， $\mathrm{Cu}^{(0)}, \mathrm{Cu}^{(\mathrm{I})}, \mathrm{Cu}{ }^{(\mathrm{II})}$ 三者の間には平衡が存在するので, 理論的に は $\mathrm{Cu}^{(\mathrm{II})}$ の青色を完全に消失させることはできない。この $\mathrm{Cu}(\mathrm{m})$ の青色は分析に当ってブランク值として取报われるのて、洞定の 精度を高める上から, 溶液の $\mathrm{O}_{2}$ 吸収前に拈ける $\mathrm{Cu}$ (II) 海度は小 さいことが望ましい。

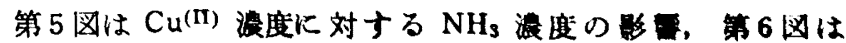


第 5 図
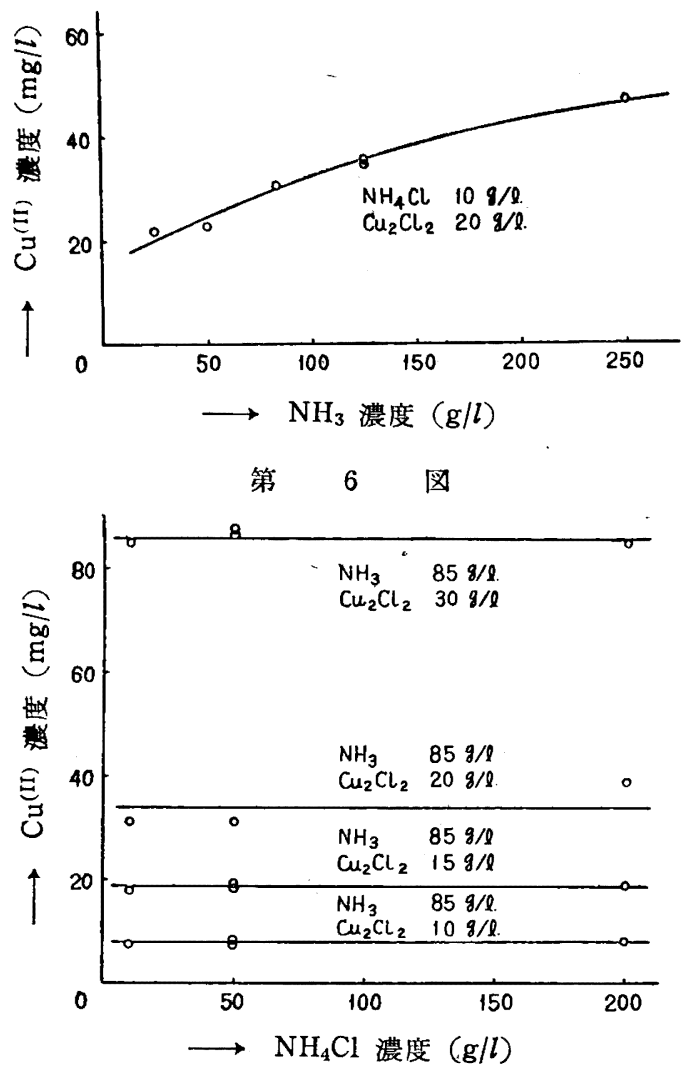

第 $\quad 7$ 図

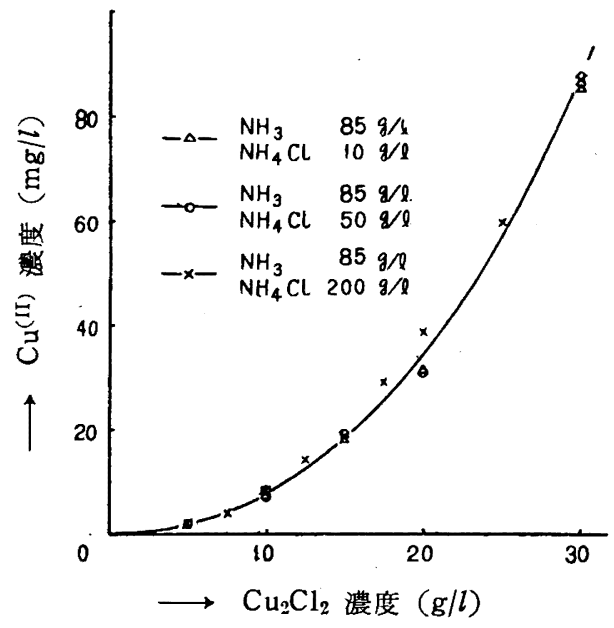

$\mathrm{NH}_{4} \mathrm{Cl}$ 濃度の影響, 第 7 図は $\mathrm{Cu}_{2} \mathrm{Cl}_{2}$ 濃度の影響をそれぞれ示 す。

これによれば, $\mathrm{NH}_{4} \mathrm{Cl}$ は $\mathrm{Cu}^{(\mathrm{II})}$ 濃度に対してほとんど無関係 であるが, $\mathrm{NH}_{3}$ 濃度の增加は平衡に扣ける $\mathrm{Cu}$ (II) 濃度を增加さ

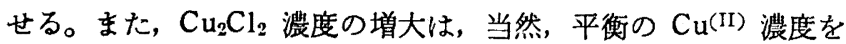
大とする。 $\mathrm{Cu}(\mathrm{I}), \mathrm{Cu}(\mathrm{I})$ の各濃度を $\mathrm{m} . \mathrm{mol} / \mathrm{l}$ で表わし, その対 数をとると両者の関係は第 8 図に示すよ5に直線的となり，その 傾斜はほぼ2に等しく，乙たがって， $\mathrm{NH}_{3}$ 性溶液に打いても中 性あるい酸性に拈ける単イオンの場合と同様に次の平衡関係が 成り立つものと思われる。

$$
\begin{aligned}
& 2 \mathrm{Cu}^{(\mathrm{I})} \underset{\mathrm{NH}_{3} \underset{\mathrm{H}^{2}}{\rightleftarrows}}{\rightleftarrows} \mathrm{Cu}^{(0)}+\mathrm{Cu}^{(\mathrm{II})} \\
& {\left[\mathrm{Cu}^{(\mathrm{II})}\right] /\left[\mathrm{Cu}^{(\mathrm{I})}\right]^{2}=K \quad(K: \text { 平衡恒数) }}
\end{aligned}
$$

これは， $\mathrm{Cu}^{+}$および $\mathrm{Cu}^{2+}$ の単イオン間の平衡，ならびにそ
第 8 図

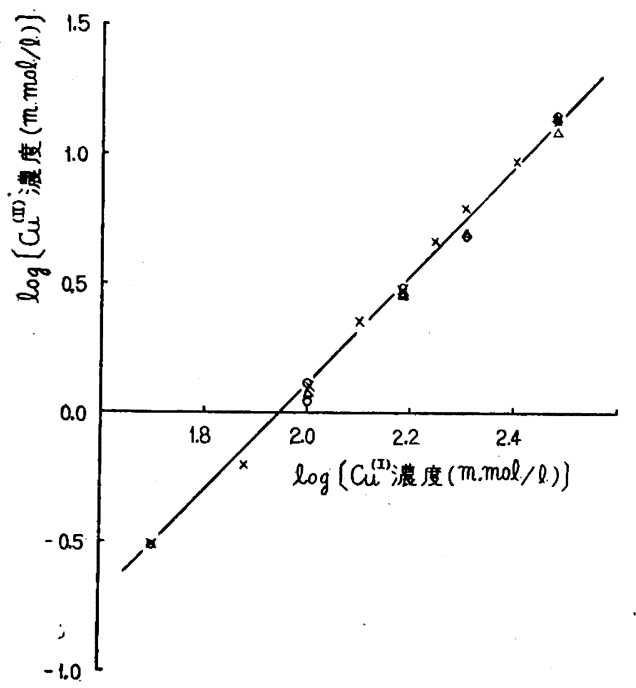

れぞれの荷数における単イオンおよび $\mathrm{NH}_{3}$ 錯イオン間の平衡関 係から容易に導かれることである。

$\mathrm{NH}_{4} \mathrm{Cl}$ の添加は $\mathrm{NH}_{3}$ の解離度に影響を与え, したがって, 上 記平衡にも影響を及ぼすはずであるが, $\mathrm{NH}_{3}$ 濃度の変化が平衡 に及ぼす影響それ自身が第 5 図に示したよ5に比較的小さいの で, $\mathrm{CH}_{4} \mathrm{Cl}$ 濃度が $0 \sim 200 \mathrm{~g} / l$ 程度の範囲ではその平衡に対する 影響も第 6 図のよ 5 に無視できる程度に小さくなるものと思われ る。

（3）考 察 $\mathrm{Cu}_{2} \mathrm{Cl}_{2}-\mathrm{NH}_{4} \mathrm{Cl}-\mathrm{NH}_{3}$ 水溶液を $\mathrm{O}_{2}$ の比色定量に 吸收液として使用する場合, 次のような性質が要求される。

1） $\mathrm{O}_{2}$ との反応速度が大きいこと。

2）金属銅との平衡に扣ける $\mathrm{Cu}(\mathrm{II})$ 濃度の小さいこと。

3） $\mathrm{Cu}^{(\mathrm{II})}$ と金属銅との反応速度が大で, 速が平衡に到達す ること。

4) 溶液の $\mathrm{NH}_{3}$ 蒸気圧は小さいこと（容積の測定等に便なよ 万に)。

5）一定 $\mathrm{Cu}(\mathrm{II})$ 量に対する呈色の濃いこと，すなわち感度の 良好なこと。また，直接測定の性能に関係はないが，実際 操作上の面から必要と思われるむのに,

6) 試薬節約の見地から, $\mathrm{Cu}_{2} \mathrm{Cl}_{2}, \mathrm{NH}_{4} \mathrm{Cl}, \mathrm{NH}_{3}$ 等の濃度は小 さいことが望ましい。

7）4）の理由を除き, 分析者の保健, 装置の保護および廃溶 液の回収等の立場から $\mathrm{NH}_{3}$ の濃度は小さいことが望まし い。

等があげられる。

しかしながら，上記項目の中には互に相反する要求のあのもあ り，実際問題としてこれらの性質をことごとく備えた組成の溶液 をうることは不可能であって，それぞれの目的に応じ最も必要と 考えられる性質に重点を打いて組成を選ばなければならない。

すなわち，たとえば 1) の $\mathrm{O}_{2}$ 吸収速度の大きい溶液をうるに は実験結果の（1）から $\mathrm{NH}_{4} \mathrm{Cl}$ を添加せず, $\mathrm{NH}_{3}, \mathrm{Cu}_{2} \mathrm{Cl}_{2}$ の各 濃度を大とすればよいわけであるが， $\mathrm{NH}_{3}$ については 4)，6）, 7）等のまた $\mathrm{Cu}_{2} \mathrm{Cl}_{2}$ については 2) の条件に反するため, むま り濃度を大とすることはできない。

金属銅 との平衡に打子る $\mathrm{Cu}(\mathrm{II})$ 濃度の增加に対して, $\mathrm{Cu}_{2} \mathrm{Cl}_{2}$ は $\mathrm{NH}_{3}$ よりも大きく影響するから, 测定に当ってブランク值と 
なる $\mathrm{Cu}^{(\mathrm{II})}$ の濃度を一定に括さ光，しかもなお， $\mathrm{O}_{2}$ 吸収率を大 にするには, $\mathrm{Cu}_{2} \mathrm{Cl}_{2}$ 濃度を增すよりは $\mathrm{NH}_{3}$ 濃度を増す方が有利 である。しかし，これにも限度があり， $\mathrm{NH}_{3}$ の濃度としては 100 $\mathrm{g} / l$ 程度が限界と思われる。また, $\mathrm{Cu}_{2} \mathrm{Cl}_{2}$ 濃度も $20 \sim 25 \mathrm{~g} / l$ が 限界であり, これ以上にすることは $\mathrm{Cu}(\mathrm{II})$ 濃度の増加から好まし くない。

吸収液は調製中, 微量の空気により一部酸化されて $\mathrm{Cu}(\Pi)$ が生 成することをまぬがれないので，金属銅の浸漬によってこれを速 かに無色の $\mathrm{Cu}^{(\Gamma)}$ に還元して扰く必要があり, 吸収液には3）の 性質がある程度满されていなければならない。 $\mathrm{Cu}$ (II) と金属銅と の反応に対しては $\mathrm{NH}_{4} \mathrm{Cl}$ が大きく影響し，無添加の場合にはそ の速度は著しく小さくなる。したがって $\mathrm{NH}_{4} \mathrm{Cl}$ の少量の添加は 必要であるが, 上記実験結果からす明らかなよ5に $\mathrm{NH}_{4} \mathrm{Cl}$ は平 衡に拈ける $\mathrm{Cu}(\mathrm{II})$ 濃度にはほとんど無関係であり，また $\mathrm{O}_{2}$ の吸 収率に対してはむしろその值を减少させる傾向を持っているの で, あまり多量加えることは無意味であり， $100 \mathrm{~g} / \mathrm{l}$ 程度が限度 と考えられる。

以上の考察の結果から, 吸収液の組成として利用できる $\mathrm{NH}_{3}$, $\mathrm{NH}_{4} \mathrm{Cl}, \mathrm{Cu}_{2} \mathrm{Cl}_{2}$ 各溶質の濃度は種々の制約を受けて比較的狭い範 囲, 寸なわち, $\mathrm{NH}_{3}$ は $100 \mathrm{~g} / \mathrm{l}$ 以下, $\mathrm{NH}_{4} \mathrm{Cl}$ は $100 \mathrm{~g} / \mathrm{l}$ 以下, $\mathrm{Cu}_{2} \mathrm{Cl}_{2}$ は 20 25 $\mathrm{g} / l$ 以下に限定されるが, なお，目的に応じて その組成を変えることによりかなり性質の異なった吸収溶液を調 製することは可能である。ちなみに, Mugdan, Sixt'1) の用いた 溶液の組成は $\mathrm{NH}_{3}$ 約 $20 \mathrm{~g} / l, \mathrm{NH}_{4} \mathrm{Cl} 30 \mathrm{~g} / l, \mathrm{Cu}_{2} \mathrm{Cl}_{2} 10 \mathrm{~g} / l$ で あるが，静止吸収法による場合は $\mathrm{NH}_{3}, \mathrm{Cu}_{2} \mathrm{Cl}_{2}$ ともにこれより
高い濃度を用いる必要があると思われる。

\section{IV. 結語}

微量酸素の比色定量に用いる $\mathrm{Cu}_{2} \mathrm{Cl}_{2}-\mathrm{NH}_{4} \mathrm{Cl}-\mathrm{NH}_{3}$ 水浴液の组 成を検討する目的をむって，この溶液と $\mathrm{O}_{2}$ との反応速度に対す る組成の影響および比色に当ってブランク值となるところの, 金 属銅と溶夜との平衡下に拈ける $\mathrm{Cu}(\mathrm{II})$ 渾度と組成との関係につ いて測定を行い，得られた結果から適当な組成についての考察を 行った。

（1）溶液と $\mathrm{O}_{2}$ ガスとの反応速度を表わす吸収率に対して, $\mathrm{NH}_{3}, \mathrm{Cu}_{2} \mathrm{Cl}_{2}$ はいずれもその濃度堌加により吸取率を增加させる が, $\mathrm{NH}_{4} \mathrm{Cl}$ はむしろ吸収率を低下させる。

（2） $\mathrm{NH}_{3}, \mathrm{Cu}_{2} \mathrm{Cl}_{2}$ はいずれるその濃度增加によって, 溶液と

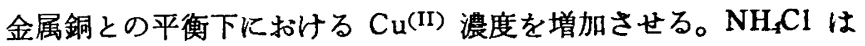
$\mathrm{Cu} \mathrm{u}^{(\mathrm{II})}$ 濃度に対してはほとんど無関係である。

（3）溶液の組成は装置の形式, 測定の目的等により適当に選 定しなければならないが， $\mathrm{O}_{2}$ の吸収溶液および比色溶液として 要求される種々の条件を考虑して, いずれの場合においてす, $\mathrm{NH}_{3}$ は $100 \mathrm{~g} / l, \mathrm{NH}_{4} \mathrm{Cl}$ は $100 \mathrm{~g} / l, \mathrm{Cu}_{2} \mathrm{Cl}_{2}$ は $20 \sim 25 \mathrm{~g} / l$ がそ れぞれ濃度の上限であると思われる。

（昭和 29 年 6 月 5 日, 電化関東支部講演会で講演）

䅂りに，本研究に際し，御助言をいたたいた舟木教授ならびに 水野所長,および種々御便宜をいたたいた昭和電工株式会社肥料 生産部，鉿木常雄前部長ならびに矢島亮一郎前課長に深く碀意を 表する。

\title{
（137）非イオン界面活性剤水溶液による金属の腐食について
}

(昭 和 30 年 12 月 8 日受理)

\author{
加藤 陽一・佐 藤 成 美*
}

\section{緒言}

近年, 界面活性剂がいろいろな方面に応用され，使用されてい るが，金属とともに使用する場合，その水溶液によって金属が腐 食されることがあり，この久陷に対して対策が必要とされてい る。しかしながら，界面活性剤の水溶液による金属の腐食につい ての研究は Ross'1), Piatti2) らの研究をはじめ, かなり系統的に も行われてはいるが，あまり多くはなく，ことに非イオン界面活 性剂水溶液については鉄に対して腐食作用が少ないこと3), 比較 的低濃度よりアルミニウムの腐食を抑制すること4) およびスズに 対する簡単な報告5）以外にはあまり見当らない。

本実験は非イオン界面活性剤 3 種の水溶液による軟鋼, 亚鉊,

* 愛知県工業指導所化学部：名古屋市千種区花田町.

1) H. Holness, T.K. Ross, J. Applied Chem. 1, 158 (1951).

2) L. Piatti, Werkstoff $\breve{u}$ Korr. 3, 186 (1952), 4, 153 (1953).

3）草野, 三雲, 工化 57, 716 (1954).

4) 草野, 三雲, 1954 年 11 月, 日化東海支部大会, 油脂討 論会講演.

5) T.K. Ross, J. Applied Chem. 2, 526 (1952).
アルミニウムおよびスズの腐食を重量の変化の測定および外钼の 変化の観察によって検討し，またこれら活性剤水溶液による离食 の防止を数種の水溶性防錆風の添加によって試みた。

\section{実 験 の 部}

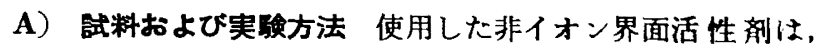
ラウリルアルコールポリエチレンオキサイド誘導体 (i)，ノニル フェノールポリエチレンオキサイド誘導体 (ii), ラウリルフミン ポリエチレンオキサイド誘導体（iii）(以下それぞれカッコを付 した記号で示す）の3種で, 竹本油脂株式会社より提供されたい、 ずれるェチレンオキサイドの重合度䄪 10 の8のである。これら はエーテルに溶解してロ過し，不溶解物を除去して使用した。供 試金属は，軟鋼は市販の冷間圧延磨帶鋼であらかじめ 250 番 : フ研磨を行ったるの，亜銛、フルミニウムは住友金属工羓妹式会 社伸銅所より提供されたもの，スズは市販のスズ板を用いた。金 属試験片の大きさおよび組成を第 1 表に示した。

蒸留水は水道水を一度蒸留したものに，カセイアルカリを加之 て再び蒸留し，溶存酸素等の筑度を一定にするため $40^{\circ} \mathrm{C}$ の恒温 恒湿槽中に 48 時間以上置いたるのを使用した。 $\mathrm{pH}$ は 6.2 6.4 (ペックマン $\mathrm{pH}$ メーターによる) である。なお各活性剂水济 